рычагов), при увеличении Аанного показателя на $1 \%$ рентабельность инвестиций нефтегазовых предприятий вырастет на $13,80 \% ; X_{8}$ - коэффициент покрытия финансовых расходов, при увеличении которого на $1 \%$ рентабельность инвестиций нефтегазовых преАприятий вырастет на 7,23\%; $X_{10}$ - темпы роста среАнесписочной численности, при его увеличении на $1 \%$ рентабельность инвестиций нефтегазовых преАприятий вырастет на 10,41\%; $X_{11}$ - соотношение дохода на оАно мицо, при увеличении которого на $1 \%$ рентабельность инвестиций нефтегазовых преАприятий снизится на 7,23\%.

Таким образом, модель оценки (2) социальноэкономической эффективности системы корпоративного управления нефтегазовыми предприятиями отображает влияние трех групп показателей на уровень рентабельности инвестиций: первая группа - показатели экономической эффективности, которые учитывают финансовое состояние преАприятия $\left(X_{4}, X_{5}\right)$; вторая группа - показатеми экономической эффективности, которые учитывают влияние внешней среды $\left(X_{6}, X_{8}\right)$; третья группа - показатели социальной эффективности $\left(X_{10}, X_{11}\right)$. То есть, на основе проведенного корремяционного и регрессионного анализа в сформированную автором модель оценки вклю- чены показатели, которые отображают как внутренние факторы, которые влияют на социальноэкономическую эффективность управления Аеятельностью преАприятия, так и те, которые учитывают изменения во внешней среде при формировании результатов деятельности преАприятий нефтегазового комплекса.

Следовательно, построенная економетрическая модемь Аает возможность оценить существующий и прогнозированный уровни социально-экономической эффективности системы корпоративного управления нефтегазовыми преАприятиями с помощью уравнения регрессии. Используя Аанные о величине и направлении Аействия показателей, которые анализируются, получены среАства Аля оценки и соответствующей корректировки текущей стратегии развития корпорации. Таким образом, с помощью инструментария корремяционно-регрессионного анализа получена модель оценки социально-экономической эффективности системы корпоративного управления нефтегазовыми преАприятиями, что позволит количественно оценить взаимосвязи межАу самыми влиятельными факторами на вемичину рентабельности инвестиций и будет способствовать повышению уровня достоверности и объективности принятия управленческих решений.

\title{
References:
}

1. SMA 4D. Retrievered October 25, 2015 from http://www.imanet.org/resources_and_publications/research_studies_resources/statements_on_management_accounting.aspx

Oksak Anastasiia,

Taras Shevchenko National University, postgraduate student, the Faculty of Economy E-mail:on_ok@mail.ru

\section{Mergers and acquisitions processes in Ukraine}

Abstract: The paper deals with characteristics of merges and acquisitions market in Ukraine. The study describes main directions and motives of integration processes at domestic enterprises. Efficient ways are suggested to improve processes of merges and acquisitions in Ukraine.

Keywords: merges and acquisitons market, motives for merges and acqusitions.

Problem statement. The current stage of development of domestic and foreign economies is characterized by the activation of integration processes which are followed by the growth of production scale and emergence of significant number of big companies. The strategic factor for 
the companies' success in the world markets and extension of international competitiveness is their market value growth. Fierce competition demands from Ukrainian producers the strategic decisionmaking on expansion and entering foreign markets, as well as application of effective mechanisms for consolidating strong positions in these markets. It's not accidentally, that merges and acquisitions are the most widespread forms of foreign direct investment, and the techniques of merges and acquisitions today serve as the most profitable business in the countries with developed economies. That's why, the question of preliminary assessment of potential deals in the merges and acquisitions market, research of consolidation process, familiarization with existing experience and prospects of merges and acquisitions in this market are of utmost importance. Hence, today the problem of building up strategies for business expansion through merges and acquisitions is urgent because the experience shows that only a small amount of national companies are able to compete with the world leaders, which can be also the aim for consolidation of transnational companies.

Analysis of recent studies and publications. The morden economic literature contains a lot of theoretical as well as applied works dedicated to different aspects of merges and acquisitions market functioning. Theoretical and applied problems, related to merges and acquisitions, have been fully highlighted by foreign authors. The questions of strategy and tactics for corporations' reorganization, assessment of company's value which are merging, the operations' financing, managing integrated companies are discussed the works of Gohan, Lazha, Rid, Rubek and others.

Among the domestic scientists, which research the problems of merges and acquisitions and analyze the investment attractiveness of corporations in the conditions of post soviet economic systems, the following authors should be noted - A. Galchynskiy, A. Kedrisova, Z. Vasylchenko, V. Geytz; among Russian scientists $-S$. Volodymyrova, N. Egorova.

The aim of the article is to analyse and determine the current state of merges and acquisitions market in Ukraine, to identify the existing problems of the this market. It also aims to estimate the prospects of this market in the nearest future.
One of the most effective ways of gaining additional development conditions is entering agreements in merges and acquisitions, so called M\&A. This type of agreements is one of the most popular development techniques, which is used even by the companies operating all over the world.

Under conditions of M\&A processes activation, it is important to orientate in the types of agreements as well as to realistically assess the main motives and the level of their effectiveness.

However, before conducting the analysis of these processes in the domestic market, it is important to consider the terminological differences when using the terms of merges and acquisitions.

For example, according to commonly accepted approaches abroad, merges and acquisitions mean the association of business entities, which results in creating the unique economic unit consisting of two or more previously existing structures.

Economists Rid and Lazhu, in turn, determine merges and acquisitions as an agreement according to which one corporation is juridically merged by another one that results in the situation when the company-absorber takes the balance of all the assets and liabilities of the company that is being merged. The separate transfer of assets or liabilities is not conducted. $[4,661]$

The company takeover is understood as the process of buying the control of one company by another, that takes hostile nature, and aimed at systematic integration of all activities, companies, which are being combined and are usually focused on the short-term perspective.

Gohan suggests such forms of reorganization as merge, consolidation and acquisition. He determines the merge with the formula $\mathrm{A}+\mathrm{B}=\mathrm{A}$, the consolidation: $\mathrm{A}+\mathrm{B}=\mathrm{A}$, where $\mathrm{C}$ is a new company, and the term "acquisition" he refers to hostile agfeements only in one situation, while in other situations herefers it to friendly as well as to hostile agreements. Herewith, he thinks that all these terms are interchable and can be used according to the size of companies that are merging; so if the companies are similar in terms of size, that is consolidation and if they are different in terms of size, that is merge [1,21-22].

Determining the motives which induce companies to perform transactions in merges and acquisi- 
tions is one of the most important questions when deciding on their expediency. Let's select the main motives for merges and acquisitions $[2 ; 3 ; 4]$ :

1. Economy of scale - the only aim of horizontal merges - is reached when the average value of costs per unit decreases with the increase in production volume. One of the sources of such economy lies in the distribution of fixed costs among the greater number production units.

2. Complementary resources. Some companies possess complementary resources. These companies will cost more after the merger compared to the value they had before the merger, because each company will buy something that was missing and will get these resources cheaper than if it had to create the by its own.

3. The motive of monopoly and competitors liquidation. In the mergers, especially of the horizontal type, the pursuit of getting or enhancing monopoly position plays the crucial role. Antitrust law restricts merges and acquisitions followed by the clear intentions to increase prices. Sometimes competitors may be acquired and closed afterwards, because it's easier to buy them and remove the price competition.

4. Complementarity in innovations sphere. The benefits from merges and acquisitions can be gained due to saving costs on high-cost works on new technologies development and creation of new types of products, as well as on investment in new technologies and new products. One company may have good researchers and engineers, but not appropriate production capacity, supply network. Other company may have supply channels, but not innovation.

5. Free resources. The company creates large cash flows and invests the rest in buying stocks of other companies.

6. Expanding the geography of influence that will allow to enter new markets when the opportunities of traditional market have been exhausted. Moreover, becoming transnational, the company limits its susceptibility to local political and economic risks.

7. The removal of ineffectiveness and management quality improvement. Merges and acquisitions of companies may aim to gain the management effectiveness that means that assets management of one of the companies was ineffective and the assets of this company will become more manageable after the merger.

8. Ensuring economic safety and improving market position. The motive of Ensuring safety (including economic - in terms of supply of raw materials and selling goods and their prices) serves as reasoning to vertical integration.

9. The difference in market price of the company and the value of its replacement. It's easier to buy an existing enterprise than to build a new one. This is advisable when the market evaluation of property complex of the target company is lower than the cost of its assets replacement.

10. The withdrawal of the capital abroad. In Ukrainian practice, the motive of withdrawal of the capital abroad is typical activity in order to ensure the capital security, and merges and acquisitions serve as a screen for these activities.

11. Taxation motives. Companies with ultrahigh profit, that have a heavy tax burden, may acquire a company with tax credits.

12. Production diversification. Diversification helps to stabilize the profit flow that is beneficial for the employees as well as for suppliers and consumers (through the extension of assortment of products and services).

13. Reducing costs on financing (operational synergy). Borrowing costs cheaper for consolidated companies than for each of them separately.

14. Personal motives of managers.

Consequently, strategic motives for merges and acquisitions are the main ones and they are influenced by internal and external factors. The main reason for performing these operations is the change in competitive environment. The process of merges and acquisitions may provide with a quick access to new markets, extension of assortment of services, achieving an optimal company size for economy of scale.

Ukrainian market of merges and acquisitions may be referred to new emerging markets which move on stage of developing ones. The small part that Ukrainian market takes on the world market of merges and acquisitions is an evidence for its immaturity. However, the dynamics of this market makes it actual to study the market in the context of world processes as well as aiming to identify its characteristics. Analyz- 
ing the world market of merges and acquisitions one may note that it has grown by $24 \%$ in 2013 , although the number of concluded agreements has declined.

The volume of Ukrainian market of merges and acquisitions in 2013 is estimated at $\$ 8$ billion compared to 5,5 billion in 2012. It's interesting that the number of deals in 2012-2013 appeared to be much greater than in the same period during the last 6 years, but the volume of the deals is still insignificant compared to 2007 (fig.1).

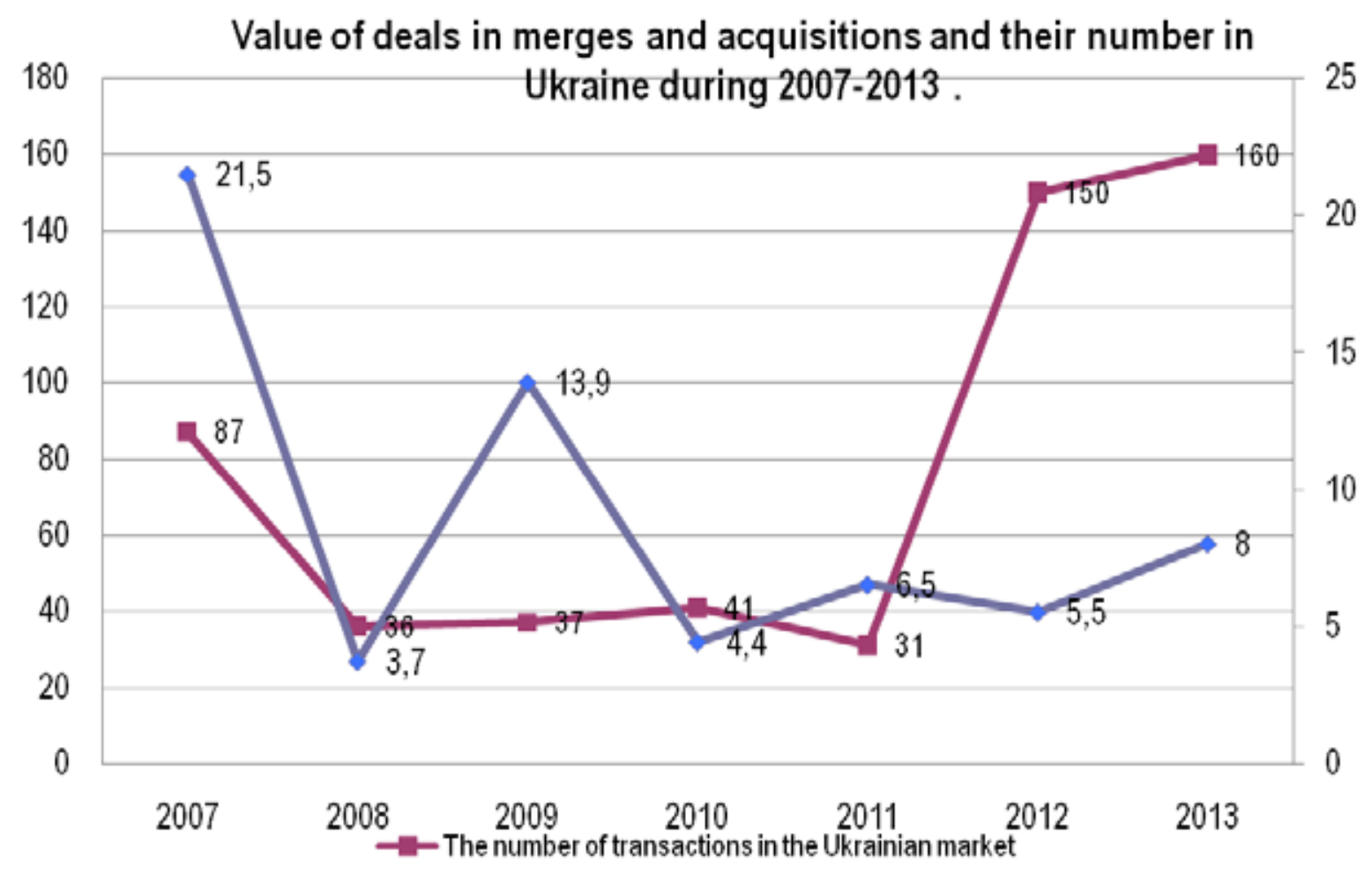

Fig. 1. Value of deals in merges and acquisitions and their number in Ukraine during 2007-2013

Source: prepared by the author according to data $[6,7]$.

The feature of domestic market of merges and acquisitions during the last two years has been the fact that investor has become to be interested in those industries, which show greater resilience to crises: food production, pharmaceutics, food retail, mechanical engineering and metallurgy. It should be also noted, that in this particular year the operations directed on the market concentration are clearly observed.

The attention of the participants of merges and acquisitions market is now focused on the financial sector and sector of trade and services as well as telecommunications sector.

Conclusion. In the nearest future the dynamics of Ukrainian market of merges and acquisitions will be influenced in many ways by the stabilization of macroeconomic situation (particularly, the predictability of exchange rate), convergence of expectations of sellers and buyers regarding the value of Ukrainian assets and recovery of the normal functioning of global credit markets.
In Ukrainian practice of merges and acquisitions the number of specific characteristics that distinguish it from the world practice may be highlighted:

- prevalence of speculative motives in the M\&A deals;

- absence of transparency and accessibility of information about the conducted agreements;

- high proportion of hostile takeovers;

- undeveloped stock market and low share of public companies that operate in the stock market;

- corruption among public authorities and their great role in the outcome of M\&A deals;

- high share value of insiders among shareholders;

- gapsinUkrainianlegislation regarding aspects of merges and acquisitions and little protection of investors' rights; ambiguity of interpretation of terms "merges" and "acquisitions" in the legislation;

— using offshore mechanisms regarding M\&A deals; 
- absence of business culture and ethics.

There are positive and negative aspects of influence of merges and acquisitions processes on Ukrainian economy. On the one side, the local companies get an opportunity for integration with foreign players and expansion into new markets and further development. The big investment projects are being implemented, which bring new and progressive developments to the country, that, in turn, increases the effectiveness of business and its competitiveness. Due to increased activity and operation scales, the amount of tax revenue to the budget of the country also increases. On the other side, merges and acquisitions may lead to the weakening competition in the market, further restructuring of the acquired company for the sake of earning short-term profit, no the synergy effect etc.

\section{References:}

1. Gohan Patrick A. Merger, Restructuring and Acquisitionss.Moscow: Alpina Business Books, 2007.$741 \mathrm{p}$.

2. Egorov A.D. Methodical bases of analysis tasks consent on economy interests of the community process enterprise ‘s M\&A. Finacial Audit and Analysis, 2007. - № 4-17 p.

3. Lysenko D. Effectiveness analysis of M\&A transactions. Audit and taxation, 2008 - № 4.

4. Maksymenko A. Trends and strategic reasons for mergers and acquisitions multinational corporations. Economic Journal XXI. - 2013. - № 9-10 (1) 2013-11-14 p.

5. Reed F. Arts of M\&A. Moscow: Alpina Business Books, 2007.- 957 p.

6. M\&A in Ukraine: Results of 2013. [Electronic resource]. - Mode of access: http://investory.com. ua/novosti/157-sliyaniya-i-pogloscheniya-v-ukraine-itogi-2013-goda.

7. M\&A in Ukraine: Results of 2013. [Electronic resource]. - Mode of access: http://mergers.com.ua

8. Tabaharnyuk M. O. Game for million: Practice Mergers and Acquisitions in Ukraine - Kyiv., 2012.$304 \mathrm{p}$. 